Article

\title{
Impact of Genetic Improvements of Rice on Its Water Use and Effects of Climate Variability in Egypt
}

\author{
Mohamed Mehana ${ }^{1,+}$, Mohamed Abdelrahman ${ }^{2, *,+} \mathbb{D}$, Yasmin Emadeldin ${ }^{1}$, Jai S. Rohila ${ }^{3}$ \\ and Raghupathy Karthikeyan ${ }^{4}$
}

1 Agricultural Economics Research Institute, Agricultural Research Center, Kafrelsheikh 33717, Egypt; mehanaeconomic@yahoo.com (M.M.); jasmin_agri_eco@yahoo.com (Y.E.)

2 Rice Research Department, Field Crops Research Institute, Agricultural Research Center, Kafrelsheikh 33717, Egypt

3 Dale Bumpers National Rice Research Center, United States Department of Agriculture-Agricultural Research Services, Stuttgart, AR 72160, USA; jai.rohila@usda.gov

4 Department of Agricultural Sciences, Clemson University, Clemson, SC 29634, USA; rkarthi@clemson.edu

* Correspondence: abdelrahman.rrtc@gmail.com

+ Authors contributed equally to this work.

check for updates

Citation: Mehana, M.; Abdelrahman, M.; Emadeldin, Y.; Rohila, J.S.; Karthikeyan, R. Impact of Genetic Improvements of Rice on Its Water Use and Effects of Climate Variability in Egypt. Agriculture 2021, 11, 865. https://doi.org/10.3390/ agriculture11090865

Academic Editors: Elisabetta Lupotto, Luigi Cattivelli and Giampiero Valè

Received: 16 August 2021

Accepted: 7 September 2021

Published: 10 September 2021

Publisher's Note: MDPI stays neutral with regard to jurisdictional claims in published maps and institutional affiliations.

Copyright: (c) 2021 by the authors. Licensee MDPI, Basel, Switzerland. This article is an open access article distributed under the terms and conditions of the Creative Commons Attribution (CC BY) license (https:// creativecommons.org/licenses/by/ $4.0 /)$.

\begin{abstract}
Developing and disseminating resilient rice cultivars with increased productivity is a key solution to the problem of limited natural resources such as land and water. We investigated trends in rice cultivation areas and the overall production in Egypt between 2000 and 2018. This study identified rice cultivars that showed potential for high productivity when cultivated under limited irrigation. The results indicated that there were significant annual reductions in both the rice-cultivated area $(-1.7 \%$ per year) and the production $(-1.9 \%$ per year) during the study period. Among the commonly cultivated varieties, Sakha101 showed the highest land unit productivity, while Sakha102 showed the highest water unit productivity. The impact of deploying new cultivars was analyzed by substitution scenarios. The results showed that substituting cultivars Giza179 and Sakha107 has the potential to increase land productivity by $15.8 \%$ and $22.6 \%$, respectively. This could result in 0.8 million $\mathrm{m}^{3}$ in water savings compared to 2018 water consumption. Long-term impacts of climate variability on the minimum and maximum temperature, relative humidity, and average precipitation during on- and off-season for rice productivity were also analyzed using an autoregressive distributed lag (ARDL) model. The results indicated that climate variability has an overall negative impact on rice productivity. Specifically, minimum temperature and on- and offseason precipitation had major long-term impacts, while higher relative humidity had a pronounced short-term impact on rice yields. The study revealed that short-duration cultivars with higher yields provided greater net savings in irrigation resources. These analyses are critical to guide the development of strategic management plans to mitigate short- and long-term climate effects on overall rice production and for developing and deploying improved rice varieties for sustainable rice production.
\end{abstract}

Keywords: ARDL; climate change; rice; sustainable production

\section{Introduction}

Egypt depends on the Nile River as its main agricultural water source, using approximately 55.5 billion cubic meters (BCM) per year. The gap between demands and the available water is approximately $13.5 \mathrm{BCM}$ /year, which is covered by official or unofficial water recycling methods [1,2]. During the last decade, water shortages were one of the major threats to the agricultural economy in Egypt. An analysis of current climatic trends indicated that the average mean temperature could increase from 1.4 to $2.5^{\circ} \mathrm{C}$ between 2050 and 2100 [3]. Higher air temperatures caused by climate variability will result in more transpiration and evaporative losses [4]. High evapotranspiration losses during the 
cropping season coupled with increasing human demands for water through increased urbanization will likely result in reduced supplies of irrigation water from the Nile River [5]. This poses a significant threat to Egyptian agriculture, particularly rice production, which requires season-long flood irrigation. Due to declining freshwater irrigation resources, there exists a tremendous need to increase water use efficiency in rice and other crops produced in Egypt and around the world [6,7].

Egypt is considered one of the most vulnerable countries facing the potential impacts of climate change [8], as the agriculture industry in Egypt consumes $\sim 84 \%$ of the country's water resources $[9,10]$. Egypt's agriculture mainly depends on irrigation from only one major source, the Nile River. With the completion of the Aswan High Dam, Egypt has been well-positioned to face drought conditions in a given year, but multiyear droughts still remain a constraint on its agriculture industry.

Rice is an important food crop for the world's food security [11-13]. Climate change may have negative impacts on the production of crops and can jeopardize the world's food security [14-18]. In Egypt, the rice crop is of further importance to farmers, as it is a high-income source compared with other summer field crops. In addition, rice is one of the major field crops in Egypt for domestic consumption. In Egypt, rice was cultivated on 360.44 thousand hectares (ha) with a total production of 3.15 million tons in 2018 [19]. It is mainly grown in the Nile River Delta, where the climate and soil conditions are suitable for its cultivation $[20,21]$. Rice is sensitive to water stress during its vegetative and reproductive stages, affecting grain yield and quality [22-24]. Several empirical solutions have been developed to address the temperature and water stress effects in rice. One of the effective solutions has been developing improved varieties with better genetic make-up, utilizing modern molecular breeding approaches [25-28]. Disseminating high-yielding rice varieties with low water consumption is of greater economic value to Egypt, as well as the rest of the global rice-growing areas.

Tantawi and Ghanem [2] reported that varietal substitutions with newly developed short-duration cultivars could save approximately $10-20 \%$ of irrigation water in Egypt, corresponding to 1.4-2.5 BCM. An extra reduction in irrigation water could be achieved faster by the utilization of modern technologies and developing new cultivars that require comparatively fewer irrigations without any reduction in grain yield and quality traits [29]. Newly improved rice varieties hold great promise toward sustainable rice production in Egypt [30].

Recently, several investigations were conducted to study the impact of climate change on yield, agriculture, and economic value of cereal crops using several techniques [31-34]. Ali et al. [35] examined the response of agricultural production time-series data between 1960 and 2014 to climatic change and its short- and long-term effects on economic growth in Pakistan using the autoregressive distributed lag (ARDL) model. The findings estimated that a $1 \%$ increase in barley and sorghum production decreases carbon dioxide emissions by $3 \%$ and $4 \%$, respectively. Furthermore, the pairwise Granger causality test shows unidirectional causality of cotton, milled rice, and sorghum production with carbon dioxide emissions. A similar approach was applied by several researchers to study the impacts of climate change on agricultural production in different countries [36-40]. To the best of our knowledge, no empirical investigation about the effects of climate change on rice productivity has been conducted in the context of Egypt. This study fills that knowledge gap.

We studied the impact of the newly developed rice varieties on the overall rice production in Egypt from 2000 to 2018. Furthermore, we compared water consumption among the most popular rice cultivars and the newly developed varieties. Several substitution scenarios are presented with the newly released high yielding varieties to aid in selecting the most appropriate variety for a specific situation to produce economically viable yields using minimal irrigation water. We also investigated the effect of climate variability on rice productivity utilizing an ARDL model. 


\section{Materials and Methods}

\subsection{Study Area and Data Sources}

Rice growing governorates or regions in Egypt are located in the Nile River Delta in northern Egypt. The main governorates are Kafr El Sheikh, Ash Sharqia, Damietta, Dakahlia, El Beheira, and Gharbia and recently, some areas in Alexandria, Ismalia, and Portsaid were added (Figure 1). These rice production areas are located at the last stretch of the Nile River just before it converges with the Mediterranean Sea. Thus, these ricegrowing areas face water shortages commonly during the cropping season. Furthermore, there is a need to grow crops, such as rice, in these areas to mitigate salinity issues due to Mediterranean Sea water intrusions. Rice crop is considered one of the major cash crops for farmers in this area, as well as a strategic crop for the country's economy and food security.

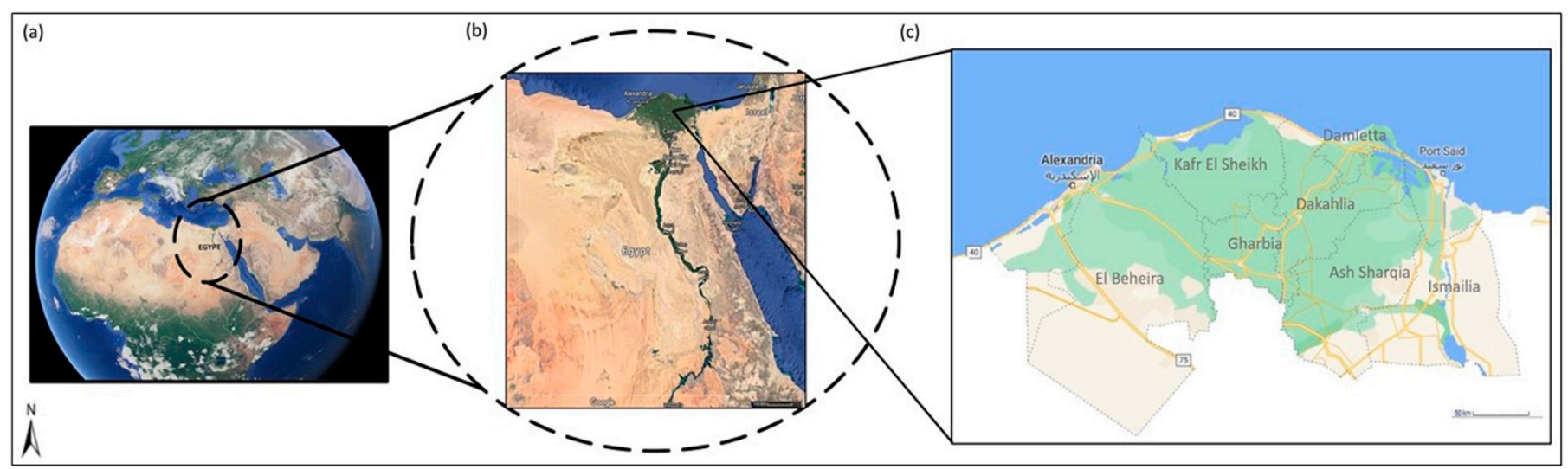

Figure 1. The location of the study area where the rice crop is cultivated in Egypt. (a) Egypt location on the northern part of the African continent; (b) location of the Nile River Delta in northern Egypt; and (c) the study areas in the rice-growing governorates. The figure was generated using google maps; https://www.google.com/maps (accessed on 3 April 2021).

We collected all relevant data related to rice production, economics, and water use from the Central Administration of Agricultural Economics, Economic Agricultural Affairs sector at Ministry of Agriculture and Land Reclamation and Central Agency for Public Mobilization and Statistics CAPMAS, Egypt (https:/ /www.capmas.gov.eg/ (accessed on 3 February 2021)). The data sources included all published and unpublished available data from the agency.

\subsection{Economic Indicators of Land and Water Productivity of Rice Cultivars}

Raw time series data of cultivated areas and yield for popular rice varieties between 2000 and 2018 were collected. Descriptive statistics and trend analyses were performed using SPSS software (SPSS Inc. Released 2008. SPSS Statistics for Windows, Version 17.0.: SPSS Inc., Chicago, IL, USA). To identify the best cultivated variety during the study period in terms of land and water productivity, we estimated several economic indicators described in the equations below:

1. Average varietal land productivity (ton $/$ ha) $=$ average varietal total rough rice grain production (ton)/average total cultivated area (ha).

2. Average varietal water use (ton/thousand $\mathrm{m}^{3}$ ) $=$ average varietal land productivity (ton/ha)/average varietal water requirement (thousand $\mathrm{m}^{3}$ of water used /ha).

3. Average varietal water productivity (thousand $\mathrm{m}^{3} /$ ton) $=$ average varietal water requirement (thousand $\mathrm{m}^{3}$ of water used / ha)/average varietal land unit productivity (ton/ha). 


\subsection{Economic Projections of Water Saving by Substituting Newly Developed Rice Varieties}

We employed the projections of varietal substitutions to estimate the expected amount of water and land savings. These projection scenarios were developed using the following equations:

1. Total varietal water consumed in rice fields in 2018 as the base year $\left(\mathrm{m}^{3}\right)=$ average varietal water requirements for $2018\left(\mathrm{~m}^{3} / \mathrm{ha}\right) \times$ total varietal cultivated area (ha) for 2018.

2. Projected water savings $\left(\mathrm{m}^{3}\right)=$ projected varietal water consumption for the total cultivated area in $2018\left(\mathrm{~m}^{3}\right)$ - water consumption in rice fields for $2018\left(\mathrm{~m}^{3}\right)$.

3. Equivalent cultivated area from the water savings (ha) $=$ projected water savings $\left(\mathrm{m}^{3}\right)$ /varietal requirements per hectare $\left(\mathrm{m}^{3} / \mathrm{ha}\right)$.

4. Equivalent production from the saved water $($ ton $)=$ varietal land productivity (ton/ha) $x$ equivalent cultivated area from the water savings (ha).

5. Production after substitution (ton) $=$ average new varietal land productivity (ton/ha) $\times$ total substituted cultivated area in 2018 (ha).

6. Increase in production due to substitutions (ton) $=$ projected production after substitutions (ton) - actual production in 2018 (ton).

7. Increase in production percentage $(\%)=$ [increase in production due to substitutions (ton)/actual production in 2018 (ton) $] \times 100$.

8. Number of beneficiary people from the projected increase in production $=$ increase in production due to substitutions (ton)/average per capita rice consumption (ton/person).

\subsection{Estimating the Impact of Climate Variability on Rice Productivity}

We applied an ARDL model to examine possible cointegrations of long- and short-term relationships among rice productivity and climate change-related parameters, including minimum and maximum temperatures, relative humidity, and average precipitation during on- and off-season throughout the study period from 2000 to 2018. The climate data were acquired from the NASA POWER project for agricultural needs (https: / / power.larc.nasa. gov / (accessed on 28 January 2021)). The bounds test was primarily computed based on the predestined error correction version of the ARDL model by the ordinary least square estimator [41,42]. ARDL modeling was conducted following the standard protocols and procedures previously developed $[36,43,44]$. Pesaran et al. [42] suggested using stability tests known as the cumulative sum (CUSUM) and cumulative sum of squares (CUSUMSQ) described by Brown et al. [45] to test the stability of the coefficient in the estimated models. Accordingly, we conducted diagnostic and stability tests to ensure the goodness of the ARDL model. Finally, the data were analyzed using the Eviews 10 software package to generate the ARDL equations following the users' guidelines [46].

\section{Results and Discussion}

\subsection{Cultivated Area and Annual Production of Popular Rice Cultivars}

The cultivated rice area was divided into two categories: total rice production area and total area under popular cultivars, identified by historic adaptation, growers' choice, climate resiliency, and market value. There was a slight increase in rice-cultivated areas between 2000 and 2008, followed by a sharp decrease until 2010, then a slight increase until 2017, and a sharp decrease from 2017 to 2018 (Table 1). These fluctuations in the cultivated area were mainly due to the water regulations imposed by the government based on the local needs and freshwater availability. As water shortages became a more significant threat in Egypt, more restrictions to rice irrigation were imposed in 2018, probably causing a sharp decline in the cultivated area to a record minimum of 347.53 thousand hectares (Figure 2a). 
Table 1. Descriptive statistics for annual rice-cultivated area and rice production in Egypt between 2000 and 2018.

\begin{tabular}{cccccc}
\hline Variable & Minimum & Maximum & Mean & Skewness & Kurtosis \\
\hline Cultivated rice area $\left(10^{3}\right.$ ha) & 347.532 & 716.238 & 572.057 & -0.949 & 1.905 \\
Total rice production $\left(10^{3}\right.$ ton) & 3121.860 & 7240.520 & 5664.447 & -0.892 & 1.739 \\
Rice land productivity (ton/ha) & 8.983 & 10.463 & 9.869 & -0.675 & 0.985 \\
\hline
\end{tabular}
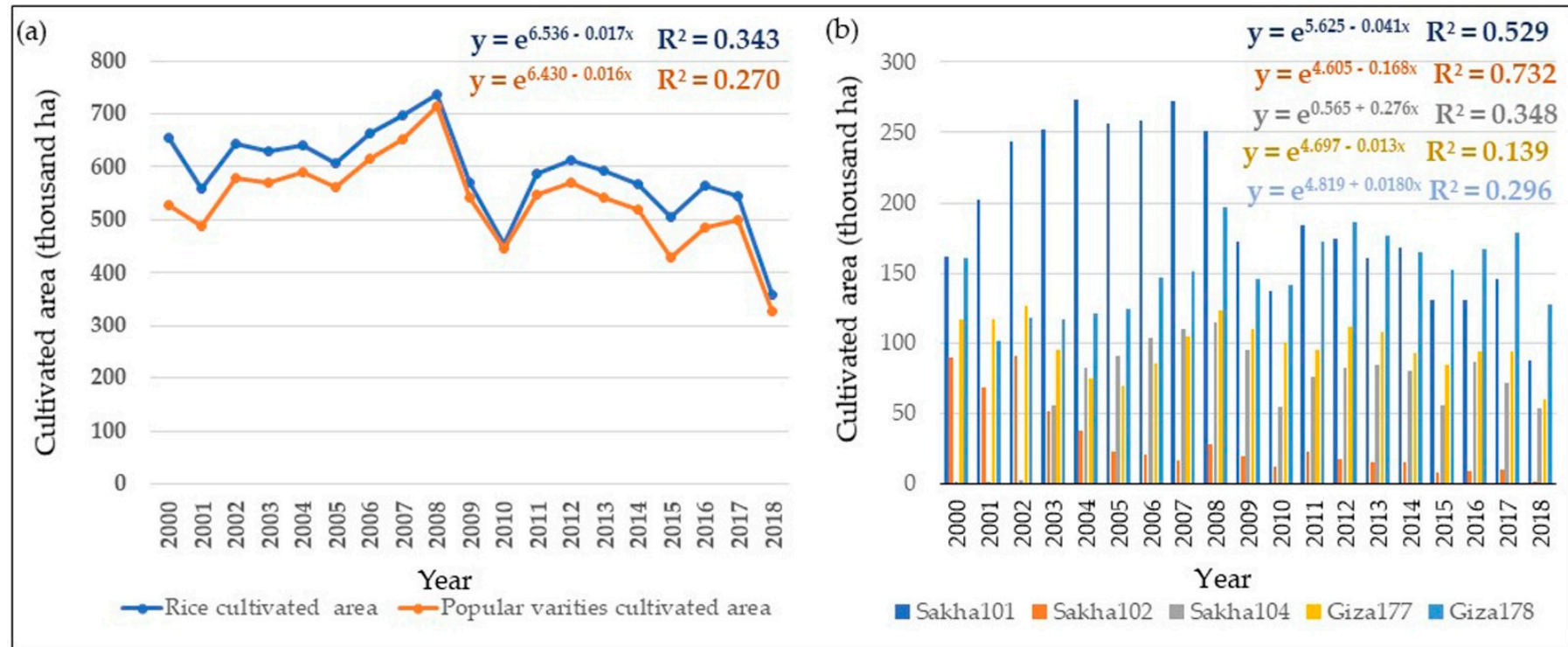

Figure 2. Rice-cultivated area in each year during the study period (2000-2018). (a) Total rice-cultivated area (blue line) and the cumulative cultivated area under popular cultivars as one group (orange line). (b) Cultivated area under each of the top five popular cultivars (shown in different color bars) in each year; $y$ is the function generated by conducting the growth regression analysis of the cultivated area (y) to the time series using SPSS software. $\mathrm{R}^{2}$ refers to the coefficient of determination of the growth regression model that determines the proportion of variance in the dependent variable (y) that can be explained by the time series. Data source: Economic Agricultural Affairs Sector-Ministry of Agriculture and Land Reclamation, Egypt.

Overall, there was a significant decrease in the rice-cultivated area, with an annual reduction rate of $1.7 \%$. The cultivated area under popular cultivars showed a similar trend (Figure 2b).

Cultivars Giza177, Giza178, Sakha101, Sakha102, and Sakha104 were among the most popular varieties during the study period, as their relative popularity was reflected by an average of $91.92 \%$ of the total cultivated area. Sakha101, a japonica variety, showed the highest relative popularity among all the cultivars based on the cultivated area and consumer preference for short grains over long grain rice. A significant cultivated area increase was detected for the cultivars Giza178 and Sakha104, while the cultivated area of Sakha101 and Sakha102 decreased significantly (Figure 2b). In contrast, no significant increase in cultivated area was observed for the cultivar Giza177 (Figure 2b).

Trends in the rice-cultivated areas were reflected in annual rice production during the study period, as validated by a strong association between rice-cultivated area and its total production $(98.7 \%)$. The highest and lowest annual rice production estimates were recorded during 2008 and 2018, with 7240.52 and 3121.86 thousand tons, respectively (Figure 3). 


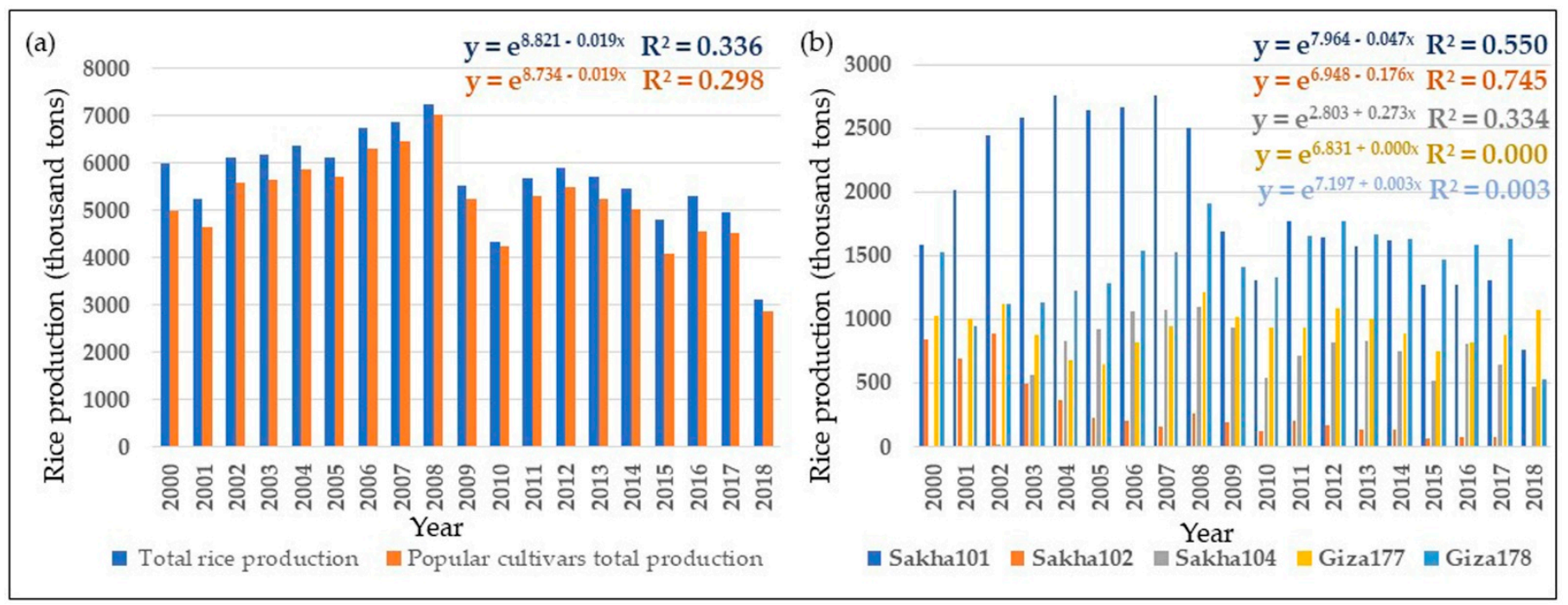

Figure 3. Rice production in each year during the study period (2000-2018). (a) Total rice production (blue bar) and the cumulative total production from the popular cultivars as one group (orange bar). (b) Total rice production from each of the top five popular cultivars (shown in different color bars) in each year; $y$ is the function generated by conducting a growth regression analysis of the grain yields (y) to the time series by using SPSS software. $\mathrm{R}^{2}$ refers to the coefficient of determination of the growth regression model that determines the proportion of variance in the dependent variable (y) that can be explained by the time series. Data source: Economic Agricultural Affairs Sector-Ministry of Agriculture and Land Reclamation, Egypt.

A significant annual decline $(1.9 \%)$ in total rice production was reported during the last two decades (Figure 3a). The total annual rice production from the most popular rice cultivars was found to significantly contribute to the total rice production (Figure 3a). Among these cultivars, annual production was the highest for Sakha101, followed by Giza178. It is interesting to note that cultivar Sakha101 showed a significant decline rate of $4.7 \%$ from its overall annual mean production of 1905.3 thousand tons. This was due to the decrease in its corresponding cultivated area. Giza177 and Giza178 had nonsignificant increased production, reflecting their non-fluctuating production estimates during the study period (Figure $3 b$ ).

\subsection{Economic Indicators of Land and Water Productivity of Rice Cultivars}

With the increase in population, the demand for rice, being a staple food, is increasing as well. Unfortunately, this increased demand has to be fulfilled with decreasing cultivable areas and limited irrigation water resources. Varietal improvement of rice cultivars plays a pivotal role in increasing productivity per unit land area and water used for its production [47,48]. The average annual land productivity and water use efficiency, and water productivity of popular Egyptian rice cultivars were analyzed in this study (Table 2). The average land productivity of these cultivars was estimated as 9.58 tons per hectare, while the cultivars Sakha101 and Giza177 recorded the highest and lowest average productivity per hectare, respectively. These results also indicated that Sakha101 represents $2.19 \%$ higher productivity compared with the average of popular cultivars. This is equivalent to increasing rice production by 32.58 thousand tons annually. Recently, Gaballah et al. [30] reported that Sakha101 and Giza179 were the best performing inbred genotypes in a study that was conducted under water stress conditions. On the other hand, the average water use efficiency for the cultivars under the current study was estimated to be 0.78 ton/thousand $\mathrm{m}^{3}$. Cultivar Sakha102 averaged the highest water use efficiency with a total annual water savings of approximately 0.06 ton $/ 1000 \mathrm{~m}^{3}$ over the average value (Table 2), which could be due to its high yielding ability with shorter days to maturity compared to the other cultivars. These results are consistent with the findings of other 
studies that estimate the potential of water savings up to $140 \mathrm{~mm}$ by using delayed rice plantings with short-duration varieties [49].

Table 2. Average land productivity, water use efficiency, and water productivity of popular rice cultivars in Egypt.

\begin{tabular}{|c|c|c|c|c|c|c|}
\hline \multirow[b]{2}{*}{ Cultivar } & \multicolumn{2}{|c|}{ Land Productivity $^{1}$} & \multicolumn{2}{|c|}{ Water Use Efficiency ${ }^{1}$} & \multicolumn{2}{|c|}{ Water Productivity $^{1}$} \\
\hline & Ton/ha & $\%$ of the Mean & Ton/Thousand $\mathrm{m}^{3}$ & $\%$ of the Mean & $\begin{array}{c}\text { Thousand } \\
\mathrm{m}^{3} / \text { ton }\end{array}$ & $\%$ of the Mean \\
\hline Giza177 & 9.26 & 96.66 & 0.81 & 103.85 & 1.24 & 96.88 \\
\hline Giza178 & 9.62 & 100.42 & 0.77 & 98.72 & 1.30 & 101.56 \\
\hline Sakha101 & 9.79 & 102.19 & 0.73 & 93.59 & 1.37 & 107.03 \\
\hline Sakha102 & 9.62 & 100.42 & 0.84 & 107.69 & 1.19 & 92.97 \\
\hline Sakha104 & 9.62 & 100.42 & 0.77 & 98.72 & 1.30 & 101.56 \\
\hline Mean & 9.58 & 100.00 & 0.78 & 100.00 & 1.28 & 100.00 \\
\hline
\end{tabular}

Data Source: Annual Reports of Agricultural Economic Affairs Sector, Ministry of Agriculture and Land Reclamation, Egypt. ${ }^{1}$ Calculated by utilizing the equations explained in Section 2.2.

\subsection{Economic Projection of Water Savings by Substituting the Newly Developed Rice Cultivars}

Several rice cultivars were developed in Egypt during the study period to overcome different biotic and abiotic stresses. Considering water as one of the current major threats to Egyptian rice cultivation, several rice varieties were released during the last decade that have lower water requirements. Giza179, Sakha107, and Sakha108 are high yielding rice cultivars with varying maturity days that were released in 2012, 2016, and 2018 (Supplementary Table S1). We investigated the effects of improved varieties by providing projections of the possible substitutions of all cultivars with the cultivars that had been recently released as well as the popular cultivar Sakha102, which had shown significant water savings in the past. The projection scenarios were realized for the total annual cultivated area and production for 2018 as the base year.

\subsubsection{Projections for Substituting Rice Cultivation with Sakha102 or Similar Cultivars}

Sakha102 was one of the old popular cultivars used during the study period and was released for cultivation in the late 1990s. It was concluded from the previous section that Sakha102 was the best in terms of water use efficiency (Table 2). Accordingly, we projected a substitution of all cultivars with Sakha102 and investigated the effect of cultivar substitution on yield and water consumption. Evidently, the substitution had a positive effect, saving approximately 291.79 thousand $\mathrm{m}^{3}$ of water (Figure 4 and Table 3), sufficient to produce approximately 227.96 thousand more tons of rice. We estimated that this substitution would increase the overall rice production by $9.25 \%$ (equivalent to 0.29 million tons), with the potential to feed 6.32 million more people.

\subsubsection{Projection of Substitution with the Newly Released Cultivars}

Giza179, Sakha107, and Sakha108 are among the newly released rice varieties in Egypt. To investigate the role of genetic improvements in decreasing water consumption and increasing water use efficiency, we projected the impacts of the substitution of such cultivars on water savings and overall rice production. Substitution of Giza179 or Sakha107 was found to save approximately 795.55 thousand $\mathrm{m}^{3}$ of water (Table 3 and Figure 4), which is sufficient to produce an additional 621.53 thousand tons of rice annually. These water savings can be utilized to irrigate an additional 63.29 thousand hectares of rice fields. Substituting rice cultivation in Egypt with Giza179 or Sakha107 has the potential to increase rice production by approximately 0.71 and 0.50 million tons, respectively, which is approximately $22.60 \%$ and $15.79 \%$ higher than the current annual production levels (Figure 4 and Table 3). Such an increase can allow feeding an additional 15.44 and 10.79 million people when analyzed and compared with the per capita consumption in the country. The results of the latest rice cultivars are comparable or even better to those for the older popular cultivar Sakha102 in both projected production and water consumption 
(Figure 4). In one case where the projected substitution of the newly released high yielding Sakha108 cultivar showed less projected water savings than that of Sakha102, a probable reason may be differences in days required for maturity (135 days for Sakha108 vs. 125 days for Sakha102, Supplementary Table S1). However, Sakha108 showed higher projected grain production after the substitution, with a $22.60 \%$ increase in current production.

An overall conclusion from the projected substitution analysis indicated a positively higher grain production with less water consumption, which will lead to securing more food for 6.32 (cv. Sakha102), 10.79 (cv. Sakha107), 15.44 (cv. Giza179) and 15.44 (cv. Sakha108) million additional people. Moreover, the study also revealed that short duration cultivars with higher yield potential provided greater net savings in irrigation resources.

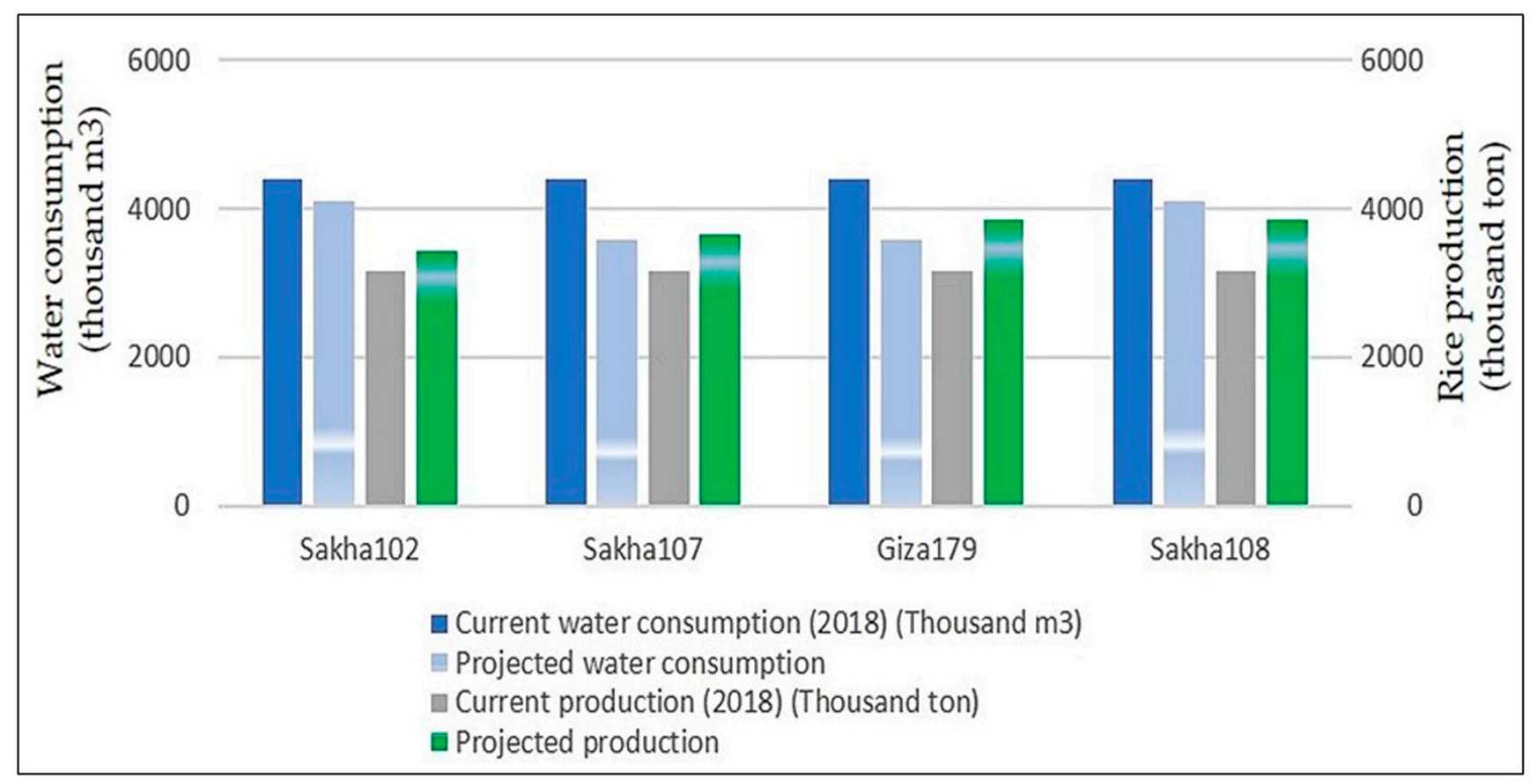

Figure 4. Annual water consumption and rice production for different substitution scenarios with improved and popular rice cultivars.

Table 3. Projections of various scenarios of cultivar substitution with Sakha102 and newly released cultivars.

\begin{tabular}{|c|c|c|c|c|}
\hline Variables 1 & Sakha102 & Sakha107 & Giza179 & Sakha108 \\
\hline Average land productivity (ton/ha) & 9.62 & 10.20 & 10.80 & 10.80 \\
\hline Water savings after substitution (thousand $\mathrm{m}^{3}$ ) & 291.79 & 795.55 & 795.55 & 274.19 \\
\hline $\begin{array}{l}\text { Equivalent production of the saved water due to the substitution } \\
\text { (thousand tons) }\end{array}$ & 227.96 & 621.52 & 621.52 & 214.21 \\
\hline Equivalent area of the saved water (thousand hectares) & 23.40 & 63.29 & 63.29 & 22.01 \\
\hline Production of the equivalent area (thousand tons) & 228.98 & 661.66 & 700.58 & 241.46 \\
\hline Production after substitution (million tons) & 3.44 & 3.65 & 3.86 & 3.86 \\
\hline Increased production amount (million tons) & 0.29 & 0.50 & 0.71 & 0.71 \\
\hline Percentage of the increased production $(\%)$ & 9.25 & 15.79 & 22.60 & 22.60 \\
\hline Equivalent increase in the number of beneficiaries (million people) & 6.32 & 10.79 & 15.44 & 15.44 \\
\hline
\end{tabular}

\footnotetext{
${ }^{1}$ Calculated by utilizing the equations explained in Sections 2.2 and 2.3 .
}

\subsection{Impact of Climate Change on Rice Crop Productivity in Egypt}

Climate change is one of the main threats facing rice production worldwide. Its impacts include an increased frequency of flooding events due to highly erratic rainy seasons, flash droughts due to extended periods without precipitation, and rising ambient 
temperatures during rice growing seasons [50]. The influence of climate change on agriculture is complex, as several patterns of climatic changes could occur and influence the outcome in any given year. We investigated the effects of four different variables related to climate change: minimum and maximum temperature, relative humidity, and average precipitation during on- and off-seasons on rice productivity (statistical profiles of the data are reported in Table 4 and Supplementary Table S2) by using the Phillips-Perron (PP) unit root test for the variable's stationarity and the ARDL model. The results from time-series analyses of the studied variables are presented in Table 5.

Table 4. Descriptive statistics for the seasonal climate change variables under study during the period 2000-2018.

\begin{tabular}{|c|c|c|c|c|c|c|}
\hline Variable * & Minimum & Maximum & Mean & $\begin{array}{c}\text { Standard } \\
\text { Deviation }\end{array}$ & Skewness & Kurtosis \\
\hline Minimum temperature $\left({ }^{\circ} \mathrm{C}\right)$ & 16.230 & 19.740 & 17.603 & 0.854 & 0.684 & 0.657 \\
\hline Maximum temperature $\left({ }^{\circ} \mathrm{C}\right)$ & 35.890 & 39.290 & 37.552 & 0.854 & 0.000 & 0.022 \\
\hline Relative humidity (\%) & 57.360 & 58.980 & 58.109 & 0.520 & 0.038 & -1.281 \\
\hline Precipitation off-season (mm/day) & 0.640 & 26.560 & 13.524 & 5.521 & 0.030 & 1.902 \\
\hline Precipitation on-season (mm/day) & 0.040 & 7.390 & 1.531 & 1.855 & 1.985 & 4.591 \\
\hline
\end{tabular}

* Seasonal climate data by years are in the Supplementary Table S2.

Table 5. Long-term and short-term coefficients from the ARDL $(1,0,0,1,0,0)$ model.

\begin{tabular}{|c|c|c|c|c|}
\hline \multicolumn{5}{|c|}{ Dependent Variable Is: $\ln Y$} \\
\hline Regressors & Coefficient Standard & Error & t-Ratio & Probability \\
\hline \multicolumn{5}{|c|}{ Panel A: long-term estimation } \\
\hline $\ln \mathrm{X}_{1}$ & $-0.425509 *$ & 0.202408 & -2.102233 & 0.0649 \\
\hline $\ln X_{2}$ & -0.321857 & 0.416219 & -0.773289 & 0.4592 \\
\hline $\ln x_{3}$ & -0.561716 & 1.455002 & -0.386058 & 0.7084 \\
\hline $\ln X_{4}$ & $0.051253^{* *}$ & 0.021499 & 2.383938 & 0.0410 \\
\hline $\ln X_{5}$ & $-0.026170 * *$ & 0.010630 & -2.461969 & 0.0360 \\
\hline $\mathrm{C}$ & 6.819653 & 5.535767 & 1.231926 & 0.2492 \\
\hline \multicolumn{5}{|c|}{ Panel B: short-term estimation } \\
\hline$\Delta \ln X_{3}$ & $-0.897679 * * *$ & 0.274232 & -3.273427 & 0.0096 \\
\hline $\mathrm{ECM}_{\mathrm{t}-1}$ & $-0.379013^{* * *}$ & 0.049276 & -7.691577 & 0.0000 \\
\hline \multicolumn{5}{|c|}{ Panel C: residual diagnostic tests } \\
\hline Adjusted R-squared & & 0.8969 & CUSUM & stable \\
\hline F-statistic & & $20.890^{* * *}$ & CUSUMSQ & stable \\
\hline Durbin-Watson stat & & 1.8607 & & \\
\hline Log likelihood & & 56.662 & & \\
\hline
\end{tabular}

${ }^{* * *}$ Significance at alpha $=0.001 ; * *$ significance at alpha $=0.05 ;{ }^{*}$ significance at alpha $=0.01 ; \mathrm{X}_{1}-$ minimum temperature; $\mathrm{X}_{2}-$ maximum temperature; $X_{3}$-relative humidity; $X_{4}$-off-season precipitation; and $X_{5}$-on-season precipitation.

The unit root test of the variables was conducted to ensure that there were no variables that were integrated in order of I (2) to prevent false outcomes [51]. The estimated results of the Phillips-Perron (PP) unit test, including at the levels of variables and at the first differences, are reported in Supplementary Table S3. We found that all variables considered in this study were stationary at I (1). These results are in agreement with those of Gershon et al., who studied the effect of climate change and agricultural production in Nigeria [52]. This result suggests a robust long-term association among the variables and supports the application of an ARDL model.

A bounds test was also conducted to assess this long-term relationship. The bounds test calculated an F-statistical value of 5.07 for the annual rice mean productivity of Egyptian cultivars. It is found to be higher than the critical values of the lower and upper bounds of the tabulated $\mathrm{F}$ at the significance level of 1.0\% (Supplementary Table S4), explaining the rejection of the null hypothesis. These results support the alternate hypothesis, i.e., the presence of the long-term association between productivity and the climate variables. 
While estimating the long-term coefficients of the ARDL model for rice crop productivity and the associated climate change parameters, the estimated $\mathrm{F}$ value was 20.89 , explaining the high significance of the ARDL model 1,0,0,1,0,0 (Table 5). A strong relationship between the climate variables and the explanatory variables was evident from the value of the adjusted coefficient of determination $\left(R^{2}=82.10 \%\right)$. This means that the changes in the productivity per hectare of rice were due to the change in the independent variables that were included in the ARDL model (Table 5).

On a long-term basis, there was a statistically significant negative impact of both minimum temperature and on-season precipitation. An increase in each of those variables by $10 \%$ resulted in a decrease in rice productivity by $4.26 \%$ and $0.26 \%$, respectively. In general, an increase in ambient temperatures leads to increased evaporative water losses coupled with increased water demand for transpiration [3]. Furthermore, the climate in Egypt during the cropping season is generally dry, and the precipitation during the summer season results mainly from water vapor and fog. It should be noted that several disease incidences are increased at high humidity and high temperature. The ARDL modeling showed a positive impact of off-season precipitation. Egypt receives its major off-season precipitation in the form of rainfall during the winter season. The model estimated that for every $10 \%$ increase in winter rainfall, there was a $0.51 \%$ increase in rice productivity (Table 5). This off-season rainfall might increase the availability of more water during the cropping season and decrease soil salinity in the root zone by flushing excess salt and replenishing the groundwater table in the region [53]. These results are in line with those obtained by Chandio et al. [36], who estimated the long-term impacts of climate change on agriculture in China. In our study, the results from the ARDL model show that climate change has a negative impact on rice crop productivity during the study period. A $10 \%$ change in each climate variable may lead to a decrease in rice productivity of as much as $12.84 \%$.

Furthermore, we also studied the short-term relationship between crop productivity and the climate variables and found a negative but significant relationship. A 10\% increase in relative humidity might result in a reduction in rice productivity by $8.9 \%$ (Table 5 ). We checked the stability of the generated ARDL model using cumulative sum (CUSUM) and the cumulative sum of squares (CUSUMSQ) tests. The CUSUM and CUSUMSQ tests were employed on the recursive regression residuals as described by Brown et al. [45]. The results indicated the stability of the generated ARDL model as explained by the critical bounds at a $5 \%$ significance level (Figure 5).

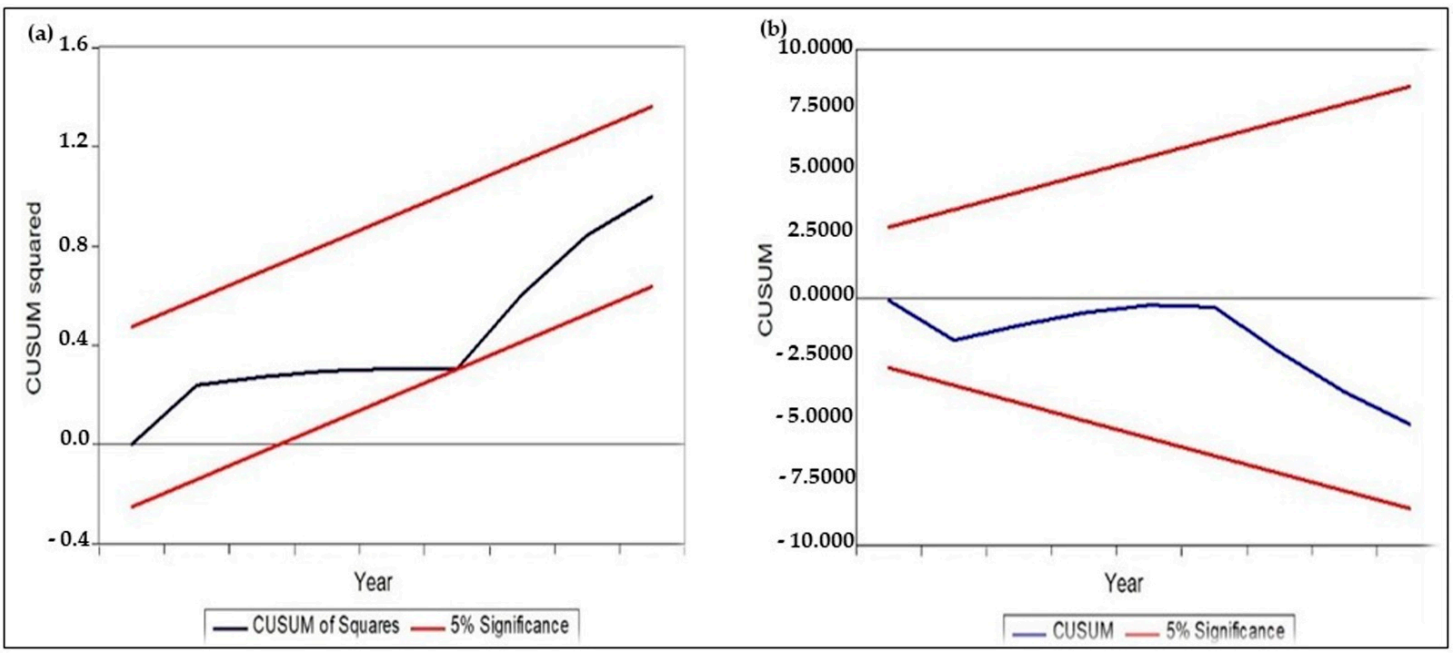

Figure 5. Stability plots for the generated ARDL $(1,0,0,1,0,0)$ model. (a) Plot of the cumulative sum of the recursive residuals. (b) Plot of the cumulative sum of squares of the recursive residuals. The straight red lines represent the critical bounds at the $5 \%$ significance level. The blue lines show the statistics for the cumulative sum of the recursive residuals and the cumulative sum of the squares of the recursive residuals. 


\section{Conclusions}

We investigated the annual rice-cultivated area and production in Egypt during the period from 2000 to 2018. A significant declining trend was observed in the cultivated area, with a declining annual rate of $1.7 \%$ during the study period. The reduction in the cultivated area was also reflected in the total production of rice crops in the country, as there was a significant declining trend of approximately $1.90 \%$ of the annual average.

Cultivars Giza177, Giza178, Sakha101, Sakha102, and Sakha104 were among the most popular cultivars during the study period accounting for $91.92 \%$ of the total rice-cultivated area. Sakha101 was the best in terms of land unit productivity, while Sakha102 had the highest average water unit productivity. Cultivar Sakha102, a shorter duration variety, required a low amount of irrigation water and maintained higher water productivity. Economic projections of cultivar substitution scenarios indicated that water savings from the newly released rice cultivars such as Giza179 and Sakha107, which are shorter duration and comparatively better yields, could save approximately 0.8 million $\mathrm{m}^{3}$ water per rice season.

The effects of climate variability on the annual productivity of Egyptian rice cultivars during the study period (2000-2018) were estimated using the ARDL model. The results indicated a significant negative long-term relationship between crop productivity per hectare and the climate variables. Even a $10 \%$ change in each climate variable would result in adverse effects on rice productivity. This long-term impact was mainly due to the minimum ambient temperature and on-season precipitation, while lower relative humidity was the main cause of negative effects on short-term rice productivity.

The results emphasize a need for more robust rice breeding programs for incorporating abiotic stress tolerance in rice, especially for water and heat stress tolerance, to mitigate the negative impacts of climate change on grain yields and safeguard food security in a sustainable manner by conserving natural resources.

Supplementary Materials: The following are available online at https: / www.mdpi.com/article/ 10.3390/agriculture11090865/s1, Table S1: Days to maturity of the studied rice cultivars; Table S2: Average minimum temperature, maximum temperature, precipitation, relative humidity, and precipitation on- and off-season of the rice-cultivated area in Egypt during cropping seasons of the study period; Table S3: Phillips-Perron (PP) unit test results of the rice productivity and the climate change variables; Table S4: The bounds test for the existence of a long-term relationship between rice productivity and climate factors.

Author Contributions: Conceptualization, M.A. and M.M.; methodology, M.M. and Y.E.; software, M.M. and Y.E.; validation, M.A., M.M., J.S.R. and R.K.; formal analysis, M.M., M.A., Y.E., J.S.R. and R.K.; writing-original draft preparation, M.A. and M.M.; writing-review and editing, M.A., J.S.R. and R.K. All authors have read and agreed to the published version of the manuscript.

Funding: USAID/STDF Junior Scientist Development Visit Grant: U.S.-Egypt S\&T Joint Fund Cycle 19 to MAA helped in establishing this research collaboration.

Data Availability Statement: All the data explained in this paper is available up on request.

Acknowledgments: The authors are thankful to Rice Research and Training Center, Field Crops Research Institute and Agricultural Economics Research Institute, Agricultural Research Center, Egypt, for their financial support and for the availability of the data. The authors sincerely acknowledge Anna McClung, Research Leader USDA-ARS, for constructive comments on the manuscript.

Conflicts of Interest: The authors declare no conflict of interest.

\section{References}

1. Omar, M.E.D.M.; Moussa, A.M.A. Water management in Egypt for facing the future challenges. J. Adv. Res. 2016, 7, 403-412. [CrossRef]

2. Tantawi, B.A.; Ghanem, S.A. Water Use Efficiency in Rice Culture. In Future of Water Management for Rice in Mediterranean Climate Areas; Chataigner, J., Ed.; CIHEAM: Montpellier, France, 1999; pp. 39-45. 
3. Agrawala, S.; Moehner, A.; El Raey, M.; Conway, D.; Van Aalst, M.; Hagenstad, M.; Smith, J. Development and Climate Change in Egypt: Focus on Coastal Resources and the Nile; Working Party on Global and Structural Policies (WPGSP): Paris, France, 2004; pp. 1-68.

4. Sadok, W.; Lopez, J.R.; Smith, K.P. Transpiration increases under high-temperature stress: Potential mechanisms, trade-offs and prospects for crop resilience in a warming world. Plant Cell Environ. 2021, 44, 2102-2116. [CrossRef] [PubMed]

5. Ahmed, S.M. Impacts of drought, food security policy and climate change on performance of irrigation schemes in Sub-saharan Africa: The case of Sudan. Agric. Water Manag. 2020, 232, 106064. [CrossRef]

6. Gomaa, M.A.; Kandil, E.E.; El-Dein, A.A.M.Z.; Abou-Donia, M.E.M.; Ali, H.M.; Abdelsalam, N.R. Increase maize productivity and water use efficiency through application of potassium silicate under water stress. Sci. Rep. 2021, 11, 1-8. [CrossRef] [PubMed]

7. Wang, H.; Zhang, Y.; Zhang, Y.; McDaniel, M.D.; Sun, L.; Su, W.; Fan, X.; Liu, S.; Xiao, X. Water-saving irrigation is a 'win-win' management strategy in rice paddies-With both reduced greenhouse gas emissions and enhanced water use efficiency. Agric. Water Manag. 2020, 228, 105889. [CrossRef]

8. El-Raey, M. Impacts and implications of climate change for the coastal zones of Egypt. Coast. Zones Clim. Change 2010, 59, 1497-1506.

9. Aziz, S.A.; Zeleňáková, M.; Mésároš, P.; Purcz, P.; Abd-Elhamid, H. Assessing the Potential Impacts of the Grand Ethiopian Renaissance Dam on Water Resources and Soil Salinity in the Nile Delta, Egypt. Sustainability 2019, 11, 7050. [CrossRef]

10. Abu-Zeid, M. Water Resources Assessment for Egypt. Can. J. Dev. Stud. 1992, 13, 173-194. [CrossRef]

11. Asibi, A.E.; Chai, Q.; Coulter, J.A. Rice Blast: A Disease with Implications for Global Food Security. Agronomy 2019,9 , 451. [CrossRef]

12. Bandumula, N. Rice Production in Asia: Key to Global Food Security. Proc. Natl. Acad. Sci. USA 2018, 88, 1323-1328. [CrossRef]

13. Saito, K.; Vandamme, E.; Johnson, J.-M.; Tanaka, A.; Senthilkumar, K.; Dieng, I.; Akakpo, C.; Gbaguidi, F.; Segda, Z.; Bassoro, I.; et al. Yield-limiting macronutrients for rice in sub-Saharan Africa. Geoderma 2019, 338, 546-554. [CrossRef]

14. Kirby, J.M.; Mainuddin, M.; Mpelasoka, F.; Ahmad, M.-U.-D.; Palash, W.; Quadir, M.E.; Shah-Newaz, S.M.; Hossain, M.M. The impact of climate change on regional water balances in Bangladesh. Clim. Change 2016, 135, 481-491. [CrossRef]

15. Misra, A.K. Climate change and challenges of water and food security. Int. J. Sustain. Built Environ. 2014, 3, 153-165. [CrossRef]

16. Pearce, D.W.; Cline, W.R.; Achanta, A.N.; Fankhauser, S.; Pachauri, R.K.; Tol, R.S.; Vellinga, P. The social costs of climate change: Greenhouse damage and the benefits of control. In Climate Change 1995: Economic and Social Dimensions of Climate Change; Bruce, J.P., Lee, H., Haites, E.F., Eds.; Intergovernmental Panel on Climate Change; Cambridge University Press: Cambridge, UK, 1996; pp. 179-224.

17. Spash, C.L. The economics of climate change impacts à la Stern: Novel and nuanced or rhetorically restricted? Ecol. Econ. 2007, 63, 706-713. [CrossRef]

18. Raza, A.; Razzaq, A.; Mehmood, S.S.; Zou, X.; Zhang, X.; Lv, Y.; Xu, J. Impact of Climate Change on Crops Adaptation and Strategies to Tackle Its Outcome: A Review. Plants 2019, 8, 34. [CrossRef] [PubMed]

19. CAPMAS. Central Agency for Public Mobilization, Statistics: Annual Bulletin of Statistical Crop Area and Plant Production 2017/2018, Egypt. Available online: https:/ / www.capmas.gov.eg/Pages /Publications.aspx?page_id=5104\&Year=23541 (accessed on 3 February 2021).

20. Ahmed, T. Worth of rice cultivation in the Nile delta. In Proceedings of the 24th WEDC International Conference, Islamabad, Pakistan, 31 August-4 September 1998; pp. 279-282.

21. El-Shahway, A.S.; Mahmoud, M.M.A.; Udeigwe, T.K. Alterations in Soil Chemical Properties Induced by Continuous Rice Cultivation: A Study on the Arid Nile Delta Soils of Egypt. Land Degrad. Dev. 2015, 27, 231-238. [CrossRef]

22. Bernier, J.; Kumar, A.; Ramaiah, V.; Spaner, D.; Atlin, G. A Large-Effect QTL for Grain Yield under Reproductive-Stage Drought Stress in Upland Rice. Crop. Sci. 2007, 47, 507-516. [CrossRef]

23. Prasad, P.V.V.; Staggenborg, S.; Ristic, Z. Impacts of drought and/or heat stress on physiological, developmental, growth, and yield processes of crop plants. Response of crops to limited water: Understanding and modeling water stress effects on plant growth processes. In Advances in Agricultural Systems Modeling; American Society of Agronomy: Madison, WI, USA, 2008; Volume 1, pp. 301-355.

24. Sarvestani, Z.T.; Pirdashti, H.; Sanavy, S.A.; Balouchi, H. Study of Water Stress Effects in Different Growth Stages on Yield and Yield Components of Different Rice (Oryza sativa L.) Cultivars. Pak. J. Biol. Sci. 2008, 11, 1303-1309. [CrossRef]

25. Kumar, A.; Dixit, S.; Ram, T.; Yadaw, R.B.; Mishra, K.K.; Mandal, N.P. Breeding high-yielding drought-tolerant rice: Genetic variations and conventional and molecular approaches. J. Exp. Bot. 2014, 65, 6265-6278. [CrossRef]

26. Bailey-Serres, J.; Parker, J.E.; Ainsworth, E.A.; Oldroyd, G.E.D.; Schroeder, J.I. Genetic strategies for improving crop yields. Nature 2019, 575, 109-118. [CrossRef]

27. Cobb, J.N.; Biswas, P.S.; Platten, J.D. Back to the future: Revisiting MAS as a tool for modern plant breeding. Theor. Appl. Genet. 2019, 132, 647-667. [CrossRef]

28. Selamat, N.; Nadarajah, K.K. Meta-Analysis of Quantitative Traits Loci (QTL) Identified in Drought Response in Rice (Oryza sativa L.). Plants 2021, 10, 716. [CrossRef]

29. Serraj, R.; McNally, K.L.; Slamet-Loedin, I.; Kohli, A.; Haefele, S.M.; Atlin, G.; Kumar, A. Drought Resistance Improvement in Rice: An Integrated Genetic and Resource Management Strategy. Plant Prod. Sci. 2011, 14, 1-14. [CrossRef] 
30. Gaballah, M.M.; Metwally, A.M.; Skalicky, M.; Hassan, M.M.; Brestic, M.; El Sabagh, A.; Fayed, A.M. Genetic Diversity of Selected Rice Genotypes under Water Stress Conditions. Plants 2020, 10, 27. [CrossRef]

31. Liu, H.; Meng, C.; Wang, Y.; Li, Y.; Li, Y.; Wu, J. From landscape perspective to determine joint effect of land use, soil, and topography on seasonal stream water quality in subtropical agricultural catchments. Sci. Total. Environ. 2021, $783,147047$. [CrossRef] [PubMed]

32. Sevanthi, A.M.; Sinha, S.K.; Sureshkumar, V.; Rani, M.; Saini, M.R.; Kumari, S.; Kaushik, M.; Prakash, C.; Venkatesh, K.; Singh, G.P.; et al. Integration of Dual Stress Transcriptomes and Major QTLs from a Pair of Genotypes Contrasting for Drought and Chronic Nitrogen Starvation Identifies Key Stress Responsive Genes in Rice. Rice 2021, 14, 1-28. [CrossRef] [PubMed]

33. Sohag, A.A.M.; Arif, T.-U.; Afrin, S.; Khan, K.; Hannan, A.; Skalicky, M.; Mortuza, G.; Brestic, M.; Hossain, M.A.; Murata, Y. Insights into nitric oxide-mediated water balance, antioxidant defence and mineral homeostasis in rice (Oryza sativa L.) under chilling stress. Nitric Oxide 2020, 100, 7-16. [CrossRef] [PubMed]

34. Yang, Y.; Liu, B.; Ni, X.; Tao, L.; Yu, L.; Yang, Y.; Feng, M.; Zhong, W.; Wu, Y. Rice productivity and profitability with slow-release urea containing organic-inorganic matrix materials. Pedosphere 2021, 31, 511-520. [CrossRef]

35. Ali, S.; Gucheng, L.; Ying, L.; Ishaq, M.; Shah, T. The Relationship between Carbon Dioxide Emissions, Economic Growth and Agricultural Production in Pakistan: An Autoregressive Distributed Lag Analysis. Energies 2019, 12, 4644. [CrossRef]

36. Chandio, A.A.; Jiang, Y.; Rehman, A.; Rauf, A. Short and long-run impacts of climate change on agriculture: An empirical evidence from China. Int. J. Clim. Chang. Strat. Manag. 2020, 12, 201-221. [CrossRef]

37. Dumrul, Y.; Kilicaslan, Z. Economic impacts of climate change on agriculture: Empirical evidence from ARDL approach for Turkey. J. Bus. Econ. Financ. 2017, 6, 336-347. [CrossRef]

38. James, T.O.; Babayemi, A.W.; Abdulmuahymin, A.S.; Udomboso, C.G.; Bello, M.L. Autoregressive Distributed Lags (ARDL) Modelling of the Impacts of Climate Change on Rice Production in Kebbi State. In Proceedings of the 2nd International Conference, Professional Statisticians Society of Nigeria, Calabar, Nigeria, 10-12 April 2018; Volume 2, pp. 356-361.

39. Rahim, S.; Puay, T.G. The impact of climate on economic growth in Malaysia. J. Adv. Res. Bus. Manag. Stud. 2017, 6, 108-119.

40. Zhai, S.; Song, G.; Qin, Y.; Ye, X.; Lee, J. Modeling the impacts of climate change and technical progress on the wheat yield in inland China: An autoregressive distributed lag approach. PLoS ONE 2017, 12, e0184474. [CrossRef] [PubMed]

41. Pesaran, M.H.; Shin, Y. An autoregressive distributed lag modelling approach to cointegration analysis. In Proceedings of the Symposium for the Centennial of Ragnar Frisch, Oslo, Norway, 3-5 March 1995; p. 31.

42. Pesaran, M.H.; Shin, Y.; Smith, R.J. Bounds testing approaches to the analysis of level relationships. J. Appl. Econom. 2001, 16, 289-326. [CrossRef]

43. Eregha, P.; Babatolu, J.; Akinnubi, R. Climate change and crop production in Nigeria: An error correction modelling approach. Int. J. Energy Econ. Policy 2014, 4, 297.

44. Pickson, R.B.; He, G.; Ntiamoah, E.B.; Li, C. Cereal production in the presence of climate change in China. Environ. Sci. Pollut. Res. 2020, 27, 45802-45813. [CrossRef]

45. Brown, R.L.; Durbin, J.; Evans, J.M. Techniques for Testing the Constancy of Regression Relationships over Time. J. R. Stat. Soc. Ser. B Stat. Methodol. 1975, 37, 149-163. [CrossRef]

46. Global, I. Eviews 10 User's Guide I; IHS Global Inc.: Englewood, CO, USA, 2017.

47. Saito, K.; Asai, H.; Zhao, D.; Laborte, A.G.; Grenier, C. Progress in varietal improvement for increasing upland rice productivity in the tropics. Plant Prod. Sci. 2018, 21, 145-158. [CrossRef]

48. Tuong, T.P.; Bouman, B.A.M. Rice production in water-scare environments. In Water Productivity in Agriculture: Limits and Opportunities for Improvement; Kijne, J.W., Barker, R., Molden, D., Eds.; CAB International: Wallingford, UK, 2003 ; pp. 53-67. [CrossRef]

49. Bhatt, R.; Singh, P.; Hossain, A.; Timsina, J. Rice-wheat system in the northwest Indo-Gangetic plains of South Asia: Issues and technological interventions for increasing productivity and sustainability. Paddy Water Environ. 2021, 19, 1-21. [CrossRef]

50. Kumar, A.; Saxena, S.P. Climate change in South Asia: Impact, adaptation and the role of GI science. In Geographic Information Science for Land Resource Management; Singh, S.K., Kanga, S., Meraj, G., Farooq, M., Sudhanshu, W., Eds.; Scrivener Publishing LLC: Beverly, MA, USA, 2021; pp. 1-18.

51. Ouattara, B. Modelling the Long Run Determinants of Private Investment in Senegal; The School of Economics Discussion Paper Series 0413. Economics; The University of Manchester: Manchester, UK, 2004.

52. Gershon, O.; Mbajekwe, C. Investigating the Nexus of Climate Change and Agricultural Production in Nigeria. Int. J. Energy Econ. Policy 2020, 10, 1-8. [CrossRef]

53. Corwin, D.L. Climate change impacts on soil salinity in agricultural areas. Eur. J. Soil Sci. 2021, 72, 842-862. [CrossRef] 